\title{
Preliminary Studies of the
} Performance of Quinoa (Chenopodium quinoa Willd.) Genotypes under Irrigated and Rainfed Conditions of Central Malawi

\author{
Moses F. A. Maliro ${ }^{1 *}$, Veronica F. Guwela ${ }^{2}$, Jacinta Nyaika ${ }^{1}$ and Kevin M. Murphy ${ }^{3}$ \\ ${ }^{1}$ Bunda College Campus, Lilongwe University of Agriculture and Natural Resources, Lilongwe, Malawi, ${ }^{2}$ Chancellor College, \\ University of Malawi, Lilongwe, Malawi, ${ }^{3}$ Sustainable Seed Systems Lab, Department of Crop and Soil Sciences, \\ Washington State University, Pullman, WA, USA
}

OPEN ACCESS

Edited by:

Alpha Kamara,

International Institute of Tropical

Agriculture, Nigeria

Reviewed by:

Wouter Buytaert,

Imperial College London, UK

Nhamo Nhamo,

International Institute of Tropical

Agriculture, Zambia

Hakeem Ayinde Ajeigbe,

International Crops Research Institute

for the Semi-Arid Tropics, Nigeria

${ }^{*}$ Correspondence:

Moses F. A. Maliro mmaliro@hotmail.com; mmaliro@bunda.luanar.mw

Specialty section:

This article was submitted to Agroecology and Land Use Systems,

a section of the journal

Frontiers in Plant Science

Received: 01 September 2016 Accepted: 06 February 2017

Published: 27 February 2017

Citation:

Maliro MFA, Guwela VF, Nyaika J and Murphy KM (2017) Preliminary Studies of the Performance of Quinoa

(Chenopodium quinoa Willd.)

Genotypes under Irrigated

and Rainfed Conditions of Central

Malawi. Front. Plant Sci. 8:227.

doi: 10.3389/fpls.2017.00227
The goal of sustainable intensification of agriculture in Malawi has led to the evaluation of innovative, regionally novel or under-utilized crop species. Quinoa (Chenopodium quinoa Willd.) has the potential to provide a drought tolerant, nutritious alternative to maize. We evaluated 11 diverse varieties of quinoa for their yield and agronomic performance at two locations, Bunda and Bembeke, in Malawi. The varieties originated from Ecuador, Chile and Bolivia in South America; the United States and Canada in North America; and, Denmark in Europe, and were chosen based on their variation in morphological and agronomic traits, and their potential for adaptation to the climate of Malawi. Plant height, panicle length, days to maturity, harvest index, and seed yield were recorded for each variety under irrigation at Bunda and Bembeke, and under rainfed conditions at Bunda. Plant height was significantly influenced by both genotype and environment. There were also significant differences between the two locations for panicle length whereas genotype and genotype $\times$ environment $(G \times E)$ interaction were not significantly different. Differences were found for genotype and $G \times E$ interaction for harvest index. Notably, differences for genotype, environment and $G \times E$ were found for grain yield. Seed yield was higher at Bunda (237-3019 kg/ha) than Bembeke (62$692 \mathrm{~kg} / \mathrm{ha}$ ) under irrigated conditions. The highest yielding genotype at Bunda was Titicaca (3019 kg/ha) whereas Multi-Hued was the highest (692 kg/ha) at Bembeke. Strong positive correlations between seed yield and (1) plant height $(r=0.74)$, (2) days to maturity $(r=0.76)$, and (3) biomass ( $r=0.87$ ) were found under irrigated conditions. The rainfed evaluations at Bunda revealed significant differences in seed yield, plant biomass, and seed size among the genotypes. The highest yielding genotype was Black Seeded (2050 kg/ha) followed by Multi-Hued (1603 kg/ha) and Bio-Bio (1446 kg/ha). Ecuadorian $(257 \mathrm{~kg} / \mathrm{ha}$ ) was the lowest yielding genotype. In general the seed yields of the genotypes were lower under rainfed conditions than under irrigated conditions at Bunda. The results also highlight the need to continue evaluating a diverse number of cultivars to select for genotypes adapted to specific agro-ecological areas and across seasons in Malawi.

\footnotetext{
Keywords: quinoa, variety, drought tolerance, seed yield, harvest index
} 


\section{INTRODUCTION}

Quinoa (Chenopodium quinoa Willd.) is a highly nutritious Andean seed crop that has been a staple food for over 5000 years for the Inca Empire and among pre-Columbian Andean farming communities in South America (Wilson, 1990; Schlick and Bubenheim, 1996; Bhargava et al., 2007). Quinoa was domesticated in the Lake Titicaca region of Bolivia and Peru, and these countries remain the major producers and exporters of quinoa.

Quinoa has been recognized as a highly nutritious crop (Cusack, 1984; Jacobsen and Mujica, 2003; Wu et al., 2016), and demand for quinoa has soared in recent years in developed countries where there is more consciousness about wellness through healthy diets. The seed of quinoa is high in protein, possesses a balanced amino acid profile compared to common cereal grains, and is gluten free (Oelke et al., 1992; Alberta Agriculture Food and Rural Development [AAFRD], 2005; Wu et al., 2014). The increasing popularity of quinoa has triggered intensive breeding and agronomic and food science research and to promote its production and meet the growing market demand, including investigations of processing characteristics and market class opportunities (Aluwi et al., 2016; Kowalski et al., 2016).

Quinoa has the capacity to grow in a wide range of climatic conditions (Rojas et al., 2000; Garcia et al., 2003; Jacobsen et al., 2003). Quinoa cultivation has transcended continental boundaries such that it is now grown in several European countries including France, England, Sweden, Denmark, Holland, and Italy, as well as in China, India, Pakistan, New Zealand, Australia, Canada, and the United States, among many others (Jacobsen, 2003; Peterson and Murphy, 2014, 2015b; Bazile et al., 2016). According to Jacobsen and Mujica (2003), there is excellent potential for successfully growing quinoa where environmental conditions are similar to those of the Andean region. In areas where frost occurs, quinoa can survive night frost $\left(-8^{\circ} \mathrm{C}\right.$ for $2-4 \mathrm{~h}$ ) (Jacobsen et al., 2007). Quinoa has been reported to have high salt tolerance (Adolf et al., 2012; Peterson and Murphy, 2015a; Ruiz et al., 2016) and can grow under extremely dry conditions (Sun et al., 2014; Walters et al., 2016), including drought prone areas of Africa (Jacobsen et al., 2003).

In developing countries, particularly in Africa, the introduction of high yield, domestically grown quinoa into the diet has the potential to contribute to food and nutritional security (National Statistical Office [NSO], 2010; Babatunde et al., 2011; Food and Agriculture Organization of the United Nations [FAO], 2012a,b; United Nations [UN], 2012). With the growing demand for quinoa grain in the USA, Europe, and Asia (Jacobsen and Stølen, 1993), the crop is a potential innovative and economically promising export crop for many African countries such as Malawi. The potential for the successful introduction of quinoa into African farming systems is high as the crop is adapted to a wide range of climates and ecological zones in the Andean region where it originates. Africa can therefore take advantage of the growing world demand to produce quinoa for export (Jayne et al., 2003) in addition to contributing to its own food security.
Quinoa was first introduced to Africa in the late 1990s in Kenya and Ethiopia (Oyoo et al., 2010) and more recently in Malawi. The introduction of quinoa to Malawi was prompted by the potential contribution the crop can make to improve overall sustainable intensification of the agriculture of Malawi (Maliro and Guwela, 2015). Identification of optimally adapted varieties of quinoa to different rainfed and irrigated environments in Malawi (Ministry of Natural Resources, Energy and Environment [MoNREE], 2013) would provide an opportunity for further breeding and selection, production and consumption of quinoa and similar target environments (Maliro and Guwela, 2015; Peterson et al., 2015; Murphy et al., 2016).

The objective of this study was to introduce quinoa cultivation to Malawi and evaluate diverse quinoa varieties for plant growth and grain yield performance in two contrasting environments of Malawi, Bunda and Bembeke. In addition, we tested these genotypes under both irrigated and rainfed conditions in the more favorable agronomic environment of Bunda. Our specific aims were to identify varieties with high yields and valuable agronomic characteristics in each location, and to test for genotype $\times$ environment interactions that could provide information to breeders with the goal of developing new varieties for Malawi farmers.

\section{MATERIALS AND METHODS}

Evaluation experiments were conducted at Bunda College's Horticulture Research Farm and Bembeke Agricultural Sub Research Station. Bunda College's Horticulture Research farm is located at $14^{\circ} 12^{\prime} \mathrm{S}$ and $33^{\circ} 46^{\prime} \mathrm{E}$, at an elevation of $1200 \mathrm{~m}$ above sea level (Figure 1). The site receives an average rainfall of $1030 \mathrm{~mm} /$ year with an average temperature of $20^{\circ} \mathrm{C}$. Bembeke Agricultural Sub Research Station is located at $14^{\circ} 35^{\prime} \mathrm{S}$ and $34^{\circ}$ $43^{\prime} \mathrm{E}$, at an elevation of $1600 \mathrm{~m}$ above sea level (Figure 1). It receives an average annual precipitation of $1500 \mathrm{~mm}$ with an average temperature of $15^{\circ} \mathrm{C}$ (Kathabwalika et al., 2013).

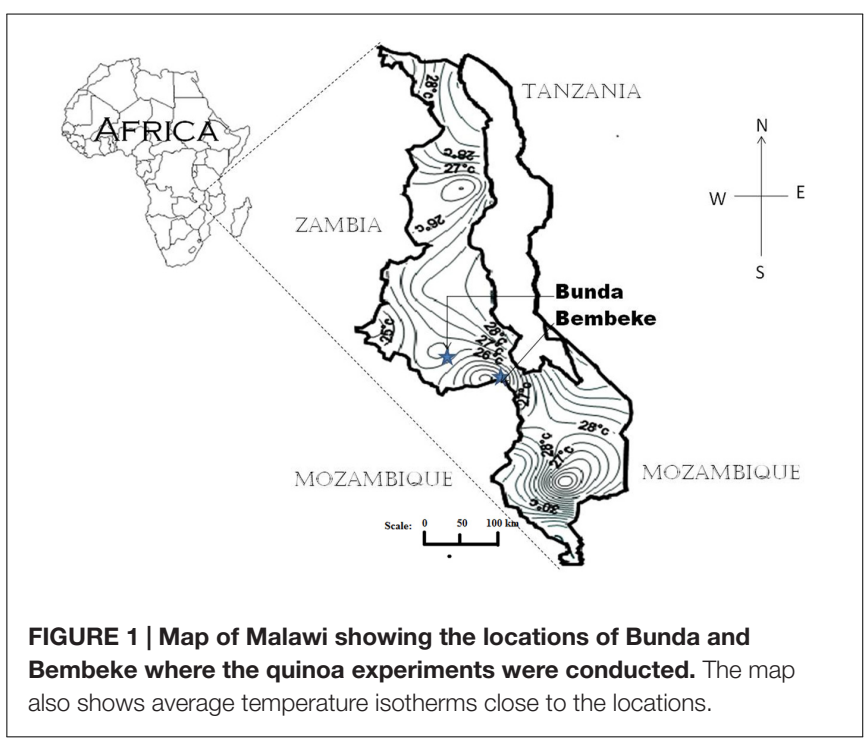


TABLE 1 | Quinoa variety, origin and background notes of the eleven varieties grown at three locations in Malawi and described in this study.

\begin{tabular}{|c|c|c|}
\hline Variety & Origin & Notes \\
\hline Ecuadorian & Ecuador & \\
\hline Black-seeded & Colorado, USA & $\begin{array}{l}\text { Developed from cross between } \\
\text { Chenopodium quinoa and } \\
\text { Chenopodium berlandieri. Very tall } \\
\text { variety (> } \mathrm{m} \text { tall) }\end{array}$ \\
\hline $\begin{array}{l}\text { Inca Red (a.k.a. } \\
\text { Pasankalla) }\end{array}$ & Bolivia & $\begin{array}{l}\text { Member of the "Salares" ecotype of } \\
\text { quinoa }\end{array}$ \\
\hline $\begin{array}{l}\text { Brightest Brilliant } \\
\text { Rainbow }\end{array}$ & Oregon, USA & $\begin{array}{l}\text { Bred by Frank Morton of Wild Garden } \\
\text { Seeds }\end{array}$ \\
\hline Bio-Bio & Chile & \\
\hline Cherry Vanilla & Oregon, USA & $\begin{array}{l}\text { Bred by Frank Morton of Wild Garden } \\
\text { Seeds }\end{array}$ \\
\hline Multi-Hued & $\begin{array}{l}\text { British } \\
\text { Columbia, } \\
\text { Canada }\end{array}$ & \\
\hline Red Head & Oregon, USA & $\begin{array}{l}\text { Bred by Frank Morton of Wild Garden } \\
\text { Seeds }\end{array}$ \\
\hline QQ74 & Chile & Heat tolerant Chilean landrace \\
\hline Puno & Denmark & Bred by Sven-Erik Jacobsen \\
\hline Titicaca & Denmark & Bred by Sven-Erik Jacobsen \\
\hline
\end{tabular}

Eleven varieties of quinoa were evaluated for plant growth and grain yield in two separate experiments, irrigated (two location years) and rainfed (one location year). The 11 varieties were chosen based on their variation in morphological and agronomic traits, and their potential for adaptation to the climate of Malawi. The varieties originated from Ecuador $(n=1)$, Chile $(n=2)$, and Bolivia $(n=1)$ in South America, the United States $(n=4)$ and Canada $(n=1)$ in North America, and, Denmark $(n=2)$ in Europe (Table 1). Evaluation for seed yield and agronomic traits under irrigated conditions was conducted in the two diverse agroecological areas of Bunda and Bembeke to better understand the potentially differing effect of temperature on the variety treatments. Evaluation of varietal treatments was conducted under rainfed conditions was done at Bunda only to get a preliminary sense of the potential for quinoa to be grown in Malawi without irrigation. The experimental design for both experiments was the same where the varieties were planted in a randomized complete block design (RCBD) with four replicates per variety. The genotypes were grown on $4 \mathrm{~m}^{2}(2 \mathrm{~m} \times 2 \mathrm{~m})$ raised beds with plants in $20 \mathrm{~cm}$ spacing between rows and $10 \mathrm{~cm}$ spacing between plants. The irrigated experiments were conducted from 1 July through mid-October 2012. Irrigation was provided using $10 \mathrm{~L}$ water-cans at $2.5 \mathrm{~L} / \mathrm{m}^{2}$ applied every 2 days from sowing to maturity at which point irrigation was withdrawn to allow plants to dry for harvesting. There was no precipitation during the entire irrigated trial period in both sites. The rainfed experiment was conducted at Bunda from 28 December 2012 to 11 April 2013 with the same spacing between rows and plants. The field was kept weed free throughout the growing season.

Data was collected from a net plot which comprised an area of $2.56 \mathrm{~m}^{2}$ (excluding the outer $20 \mathrm{~cm}$ all-round the plot). Data on traits measured included number of days to maturity, plant height at harvest $(\mathrm{cm})$, panicle length $(\mathrm{cm})$, grain yield $(\mathrm{kg} / \mathrm{ha})$, seed weight (g/1000 seeds), and harvest index. Harvested seed and biomass per plot were weighed and yield per hectare was estimated at $12.5 \%$ moisture content. The temperatures for the two sites and rainfall for Bunda Site were recorded (Figure 2). The data was subjected to two-way analysis of variance where site and genotype were two factors used in the analysis using Genstat statistical package version 17. Pearson product-moment correlation (Snedecor and Cochran, 1989) analysis was used to assess the relationship of seed yield with and 1000 seed weight. Variety and location treatments were considered fixed effects and blocks and all interaction with blocks were treated as random effects.

\section{RESULTS AND DISCUSSION}

\section{Plant Height and Panicle Length}

Under irrigated conditions, plant height at harvest was significantly influenced by both genotype $(P \leq 0.002)$ and location $(P \leq 0.001)$. The interaction between the genotype and site was not significant (Table 2). QQ74 grew to $108 \mathrm{~cm}$ tall at Bunda, followed by Bio-Bio $(98 \mathrm{~cm}$ ) (Figure 3). The plants were significantly shorter at Bembeke, with a mean height of $47 \mathrm{~cm}$ compared to $87 \mathrm{~cm}$ at Bunda (Figure 3). Bembeke is on average $5^{\circ} \mathrm{C}$ cooler than Bunda (Figure 2), and receives approximately $500 \mathrm{~mm}$ more precipitation per year. It is likely that the cooler temperatures were responsible for the shorter plant height, as cultivation occurred during the dry season and therefore irrigation would have ensured approximately equal access to water across both locations. Low temperatures similar to those experienced at Bembeke slow down enzymatic activity and leading to slow plant growth (Adams et al., 2001). At Bembeke, Bio-Bio grew to a height of $66 \mathrm{~cm}$, followed by Brightest Brilliant Rainbow $(64 \mathrm{~cm}$ ) (Tables 2, 3). Plant height was strongly correlated to seed yield (0.74), biomass (0.80), and days to maturity (0.76), but showed no association with the harvest index (Table 2).

Panicle length at harvest under irrigated conditions was different across environments $(P \leq 0.005)$, but did not vary across genotype (Table 2). The quinoa grown at Bunda had a mean panicle length of $35.5 \mathrm{~cm}$ and those at Bembeke had a mean panicle length of $29 \mathrm{~cm}$ (Table 2 and Figure 3). No genotype $\times$ environment interaction was found for panicle length. Panicle length is a yield component in quinoa and significant variation in this parameter may entail significant grain yield differences in quinoa (Long Nguyen, 2016). Genotypes with longer panicles are generally expected to give more grain yield than those with shorter panicles. In this study panicle length differences were attributed to genotype differences rather than site effect.

\section{Days to Maturity}

Under irrigation, a significant genotype $\times$ environment interaction $(P \leq 0.001)$ was found for days to maturity. The genotypes and the site were also significantly different independent of each other at $(P \leq 0.001)$ and $(P \leq 0.001)$ respectively. Maturity was strongly correlated to plant height 
A

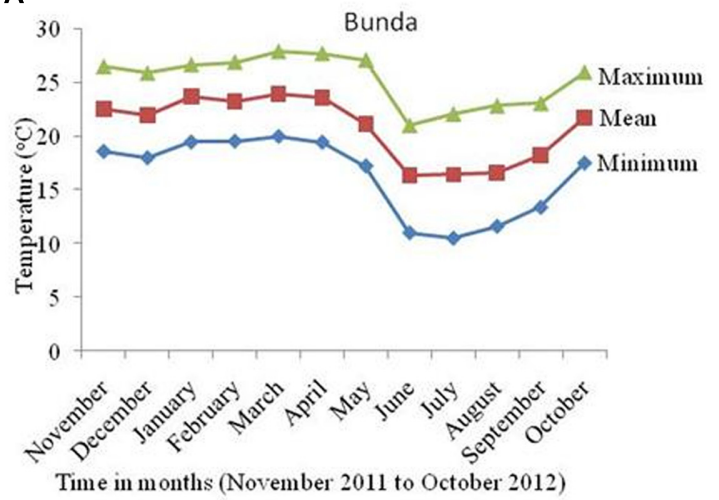

B

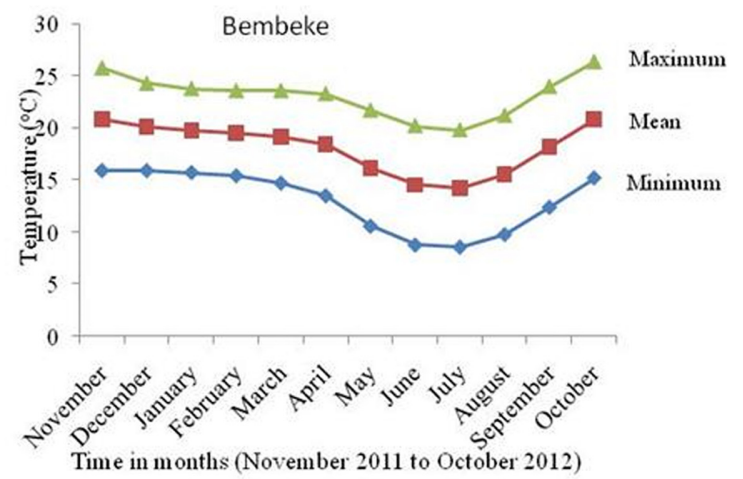

C

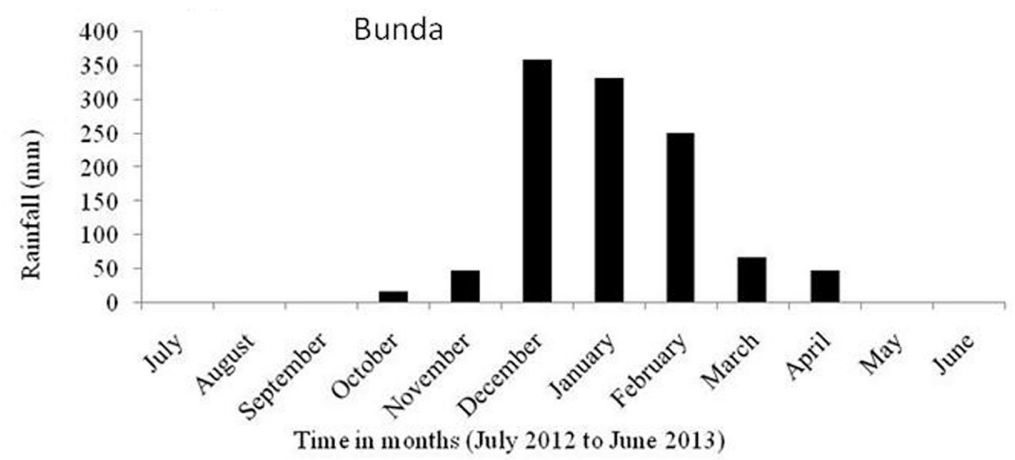

FIGURE 2 | Temperatures of Bunda (A) and Bembeke (B) locations during the dry period of 2012 when the irrigated experiments were conducted and rainfall during the rainfed experiment at Bunda in 2012/2013 (C).

TABLE 2 | Performance of quinoa genotypes planted at Bunda College Horticultural Research Farm (BD) and Bembeke Sub-Research Station (BK) and grown under irrigated conditions from June to Mid October, 2012.

\begin{tabular}{|c|c|c|c|c|c|c|c|c|c|c|c|c|}
\hline \multirow[t]{2}{*}{ Varieties/lines } & \multicolumn{2}{|c|}{$\begin{array}{l}\text { Plant height } \\
\text { (cm) }\end{array}$} & \multicolumn{2}{|c|}{$\begin{array}{l}\text { Panicle length } \\
\text { (cm) }\end{array}$} & \multicolumn{2}{|c|}{$\begin{array}{l}\text { Biomass } \\
\left(\mathrm{Kg} / \mathrm{ha}^{-1}\right)\end{array}$} & \multicolumn{2}{|c|}{$\begin{array}{c}\text { Seed size } \\
(g / 1000)\end{array}$} & \multicolumn{2}{|c|}{ Harvest index } & \multicolumn{2}{|c|}{$\begin{array}{l}\text { Grain yield } \\
\left(\mathrm{Kg} / \mathrm{ha}^{-1}\right)\end{array}$} \\
\hline & BD & BK & BD & BK & BD & BK & BD & BK & BD & BK & BD & BK \\
\hline Black Seeded & 86.0 & 41.3 & 41.33 & 27.33 & 7434 & 682 & 0.25 & 0.98 & 0.26 & 0.48 & 1966 & 413 \\
\hline Multi-Hued & 82.7 & 54.7 & 32.00 & 37.00 & 3781 & 2794 & 0.34 & 1.28 & 0.29 & 0.27 & 2916 & 692 \\
\hline Bio-Bio & 99.3 & 66.0 & 40.00 & 36.67 & 7507 & 2752 & 0.19 & 1.01 & 0.27 & 0.20 & 1983 & 559 \\
\hline Brightest BR & 96.0 & 63.7 & 30.00 & 35.00 & 8907 & 1994 & 0.30 & 1.16 & 0.37 & 0.24 & 2997 & 473 \\
\hline Red Head & 88.0 & 41.0 & 37.33 & 29.67 & 7230 & 598 & 1.00 & 1.04 & 0.27 & 0.30 & 2413 & 537 \\
\hline Cherry Vanilla & 91.7 & 55.3 & 32.67 & 28.00 & 8549 & 1064 & 1.11 & 1.14 & 0.33 & 0.24 & 2818 & 315 \\
\hline Inca Red & 72.7 & 36.0 & 27.00 & 23.00 & 3034 & 1582 & 0.45 & 1.03 & 0.10 & 0.16 & 317 & 217 \\
\hline Titicaca & 74.0 & 43.3 & 34.67 & 25.00 & 5580 & 955 & 0.28 & 1.10 & 0.56 & 0.32 & 3019 & 255 \\
\hline QQ74 & 108.3 & 47.0 & 44.33 & 30.33 & 7261 & 1414 & 0.29 & 1.20 & 0.41 & 0.50 & 2954 & 292 \\
\hline Puno & 64.0 & 41.7 & 31.00 & 31.67 & 9895 & 2500 & 0.34 & 1.28 & 0.31 & 0.32 & 2260 & 446 \\
\hline Ecuadorian & 90.7 & 21.3 & 40.33 & 19.00 & 2584 & 246 & 0.14 & 0.19 & 0.15 & 0.29 & 237 & 62 \\
\hline Mean & 86.7 & 46.5 & 35.52 & 29.33 & 7173 & 1443 & 0.42 & 1.03 & 0.30 & 0.30 & 2171 & 388 \\
\hline LSD (0.05) & \multicolumn{2}{|c|}{23.04} & \multicolumn{2}{|c|}{12.71} & \multicolumn{2}{|c|}{499.9} & \multicolumn{2}{|c|}{0.05} & \multicolumn{2}{|c|}{0.18} & \multicolumn{2}{|c|}{763.8} \\
\hline Variety ( $P$-value) & \multicolumn{2}{|c|}{0.002} & \multicolumn{2}{|c|}{0.195} & \multicolumn{2}{|c|}{$<0.001$} & \multicolumn{2}{|c|}{$<0.001$} & \multicolumn{2}{|c|}{0.001} & \multicolumn{2}{|c|}{0.001} \\
\hline Site ( $P$-value) & \multicolumn{2}{|c|}{0.001} & \multicolumn{2}{|c|}{0.002} & \multicolumn{2}{|c|}{$<0.001$} & \multicolumn{2}{|c|}{$<0.001$} & \multicolumn{2}{|c|}{0.998} & \multicolumn{2}{|c|}{0.001} \\
\hline $\begin{array}{l}\text { Variety } \times \text { Site } \\
(P \text {-value })\end{array}$ & \multicolumn{2}{|c|}{0.147} & \multicolumn{2}{|c|}{0.110} & \multicolumn{2}{|c|}{$<0.001$} & \multicolumn{2}{|c|}{$<0.001$} & \multicolumn{2}{|c|}{0.039} & \multicolumn{2}{|c|}{0.001} \\
\hline $\pm S E$ & \multicolumn{2}{|c|}{3.89} & \multicolumn{2}{|c|}{1.92} & & & & & & & & \\
\hline
\end{tabular}



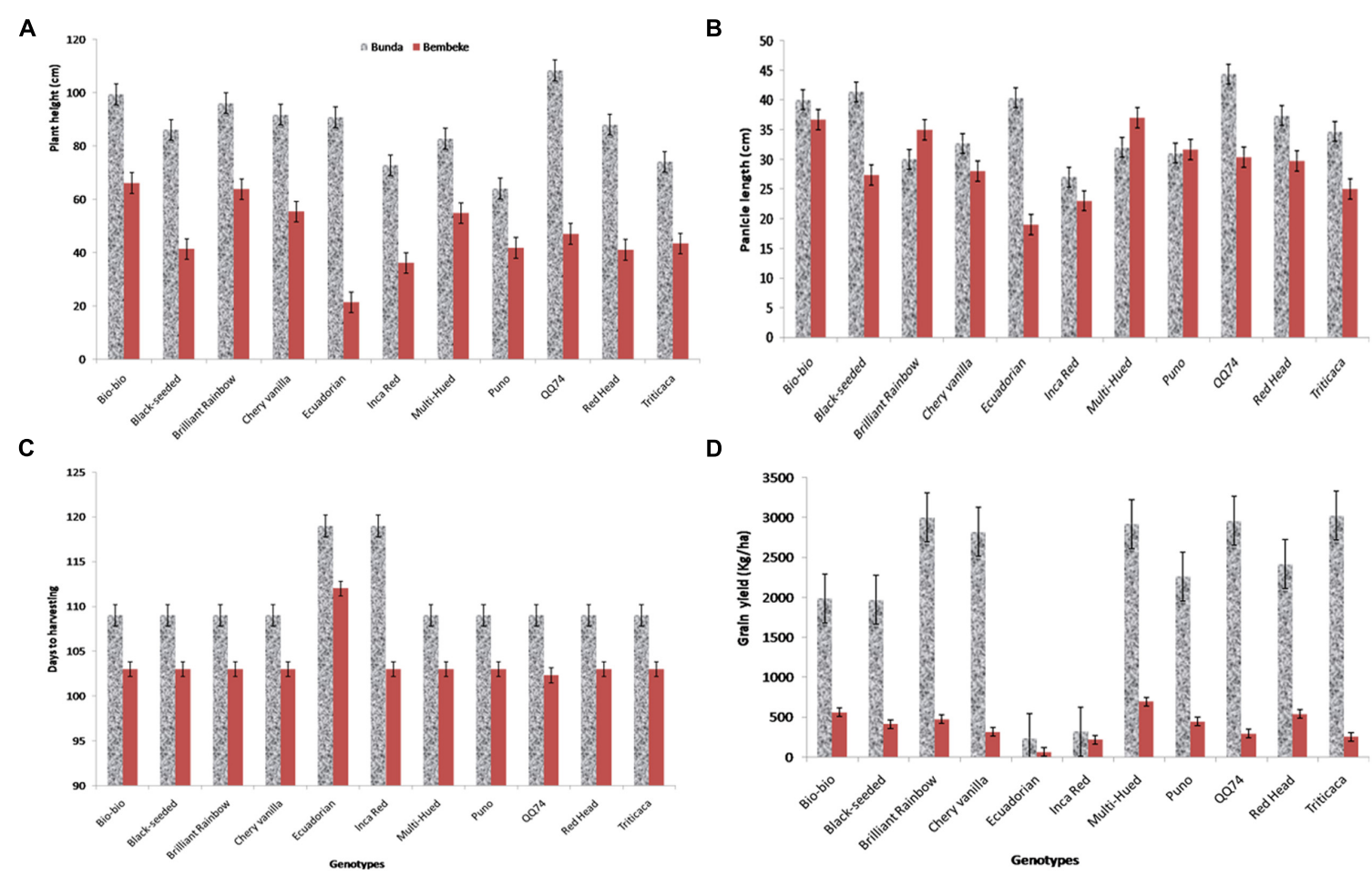

FIGURE 3 | Plant height $\mathbf{( c m )}$ at harvesting stage (A) of quinoa varieties grown at Bunda and Bembeke sites $(P=0.002$ for genotype, $P=0.001$ for environment and $P=0.147$ for genotype $\times$ environment, $G \times E)$, panicle length $(\mathrm{cm})$ at harvesting $(\mathbf{B})$ of quinoa varieties grown at Bunda and Bembeke sites, $(P=0.195$ for genotype, $P=0.002$ for environment and $P=0.110$ for $G \times E$ ), number of days taken to reach maturity (C) of quinoa varieties grown at Bunda and Bembeke sites ( $P=0.001$ for genotype, $P=0.001$ for environment and $P=0.001$ for $\mathrm{G} \times \mathrm{E}$ ) and Grain yield (kg/ha) (D) of quinoa varieties grown at Bunda and Bembeke sites in Malawi from July to October 2012 ( $P=0.001$ for genotype, $P=0.001$ for environment and $P=0.001$ for $\mathrm{G} \times \mathrm{E}$ ).

TABLE 3 | Correlation analysis for biomass, plant height, days to maturity, seed yield and harvest index of quinoa varieties grown at Bunda and Bembeke sites in Malawi under irrigation.

\begin{tabular}{lcccc}
\hline & Biomass & $\begin{array}{c}\text { Plant } \\
\text { height }\end{array}$ & $\begin{array}{c}\text { Days to } \\
\text { maturity }\end{array}$ & $\begin{array}{r}\text { Seed } \\
\text { yield }\end{array}$ \\
\hline Plant height & $0.80^{* * *}$ & & & \\
Days to maturity & $0.86^{* * *}$ & $0.76^{* * *}$ & & \\
Seed yield & $0.87^{* * *}$ & $0.74^{* * *}$ & $0.76^{* * *}$ & \\
Harvest index & -0.03 & 0.07 & -0.05 & 0.28 \\
\hline
\end{tabular}

***means significant with $p<0.001$.

(0.80), plant height (0.76), and seed yield (0.76), but did not show any relationship with harvest index (Table 3). Jacobsen et al. (1996) also reported a positive association of quinoa grain yield with maturity period (plant cycle), plant height, length and diameter of inflorescence. This association is expected as the genotypes that were early to flower, were taller at harvest and accumulated the most biomass which translated to the highest dry grain yield per ha.

The variety Ecuadorian was the slowest to mature, taking 119 days at Bunda and 112 days at Bembeke. Inca Red (Pasankala) was also slow to mature (119 days) at Bunda (Table 2 and Figure 3). These results are consistent with those of Spehar and Santos (2005), who reported that variation in days to maturity, was found to be similar among quinoa genotypes, independent of sowing dates when evaluating them across four sites in Brazil. In these results they observed that sensitivity to photoperiod and temperature in quinoa was a function of origin. Cultivars originating from the equatorial tropics were more sensitive to photoperiod and had a longer vegetative phase. Cultivars adapted to the altiplano of Peru and Bolivia were increasingly less sensitive to photoperiod the farther they originated from the equator, with the shortest vegetative phase occurring in genotypes from the highest latitudes, such as from southern Chile, northern United States, or northern Europe. This evidence indicates that to characterize growth and development of quinoa, it is necessary to analyze the response to temperature and photoperiod in all developmental phases and using a large number of genotypes (Bertero et al., 2004).

\section{Grain Yield}

A significant interaction was found between genotype and environment $(P \leq 0.001)$ for grain yield under irrigation (Table 2). Both genotype and environment effects were significantly different $(P \leq 0.001)$. Higher yields were obtained at Bunda (237-3019 kg/ha; Table 2) compared to Bembeke (62-692 kg/ha) (Figure 3). This could be the result of lower temperatures at Bembeke compared to Bunda during the time the experiments were conducted (Figure 2). Temperature is the 
TABLE 4 | Performance of quinoa genotypes planted at Bunda college farm and grown under rain fed conditions during $2012-2013$ growing season.

\begin{tabular}{|c|c|c|c|c|c|c|}
\hline Varieties/lines & $\begin{array}{l}\text { Plant height } \\
\text { (cm) }\end{array}$ & $\begin{array}{l}\text { Panicle length } \\
\text { (cm) }\end{array}$ & $\begin{array}{c}\text { Biomass yield } \\
\left(\mathrm{Kg} / \mathrm{ha}^{-1}\right)\end{array}$ & $\begin{array}{l}\text { Seed weight } \\
(g / 1000)\end{array}$ & Harvest index & $\begin{array}{l}\text { Grain yield } \\
\left(\mathrm{Kg} / \mathrm{ha}^{-1}\right)\end{array}$ \\
\hline Black Seeded & 67.3 & 59.7 & 3163 & 2.1 & 0.29 & 2050 \\
\hline Multi-Hued & 74.7 & 60.4 & 3612 & 2.0 & 0.18 & 1603 \\
\hline Bio-Bio & 68.3 & 62.3 & 2924 & 2.0 & 0.19 & 1446 \\
\hline Brightest BR & 73.6 & 40.7 & 2644 & 2.2 & 0.23 & 1386 \\
\hline Rosa Junin & 90.3 & 73.8 & 2494 & 1.9 & 0.15 & 891 \\
\hline Red Head & 69.5 & 56.4 & 2184 & 2.2 & 0.14 & 789 \\
\hline Cherry Vanilla & 73.8 & 52.0 & 2018 & 2.4 & 0.15 & 756 \\
\hline Inca Red & 56.8 & 42.6 & 1042 & 2.1 & 0.26 & 665 \\
\hline Titicaca & 69.6 & 47.0 & 2003 & 2.1 & 0.13 & 653 \\
\hline QQ74 & 72.1 & 63.9 & 2052 & 2.6 & 0.11 & 566 \\
\hline Puno & 65.0 & 41.5 & 1238 & 2.0 & 0.18 & 522 \\
\hline Ecuadorian & 62.9 & 44.6 & 623 & 1.9 & 0.15 & 257 \\
\hline Mean & 70.4 & 53.8 & 2166 & 2.14 & 0.18 & 965 \\
\hline LSD (0.05) & 19.02 & 22.55 & 837.8 & 0.24 & 0.106 & 587 \\
\hline$\pm \mathrm{SE}$ & 9.35 & 11.08 & 411.8 & 0.11 & 0.052 & 288 \\
\hline
\end{tabular}

main abiotic factors affecting quinoa growth, germination and productivity. Hirich et al. (2014) showed that low temperatures negatively affected the productivity of quinoa by increasing length of growing period. According to research conducted by Jacobsen and Bach (1998), the optimal temperature of growth for quinoa is approximately $22^{\circ} \mathrm{C}$, and Bunda was closer to this ideal than Bembeke.

The highest yielding variety at Bunda was Titicaca (3019 kg/ha), exhibiting exceptional yield potential for optimizing sustainable intensification strategies in midelevation locations where irrigation is available. Multi-Hued was the highest yielding variety $(692 \mathrm{~kg} / \mathrm{ha})$ at Bembeke (Figure 3). Multi-Hued was developed in Canada, where cooler temperatures are common during the growing season, therefore it is not surprising this variety performed well in the lower temperatures found at Bembeke. The lowest yielding variety at both sites was Ecuadorian which yielded $237 \mathrm{~kg} / \mathrm{ha}$ at Bunda and $62 \mathrm{~kg} / \mathrm{ha}$ at Bembeke (Table 2 and Figure 3). Ecuadorian also was slowest to reach maturity at both sites (112-119 days) as compared to the mean of the rest of the genotypes (101-103 days). This delayed maturity is likely a primary reason for the low yields shown in Ecuadorian. Seed

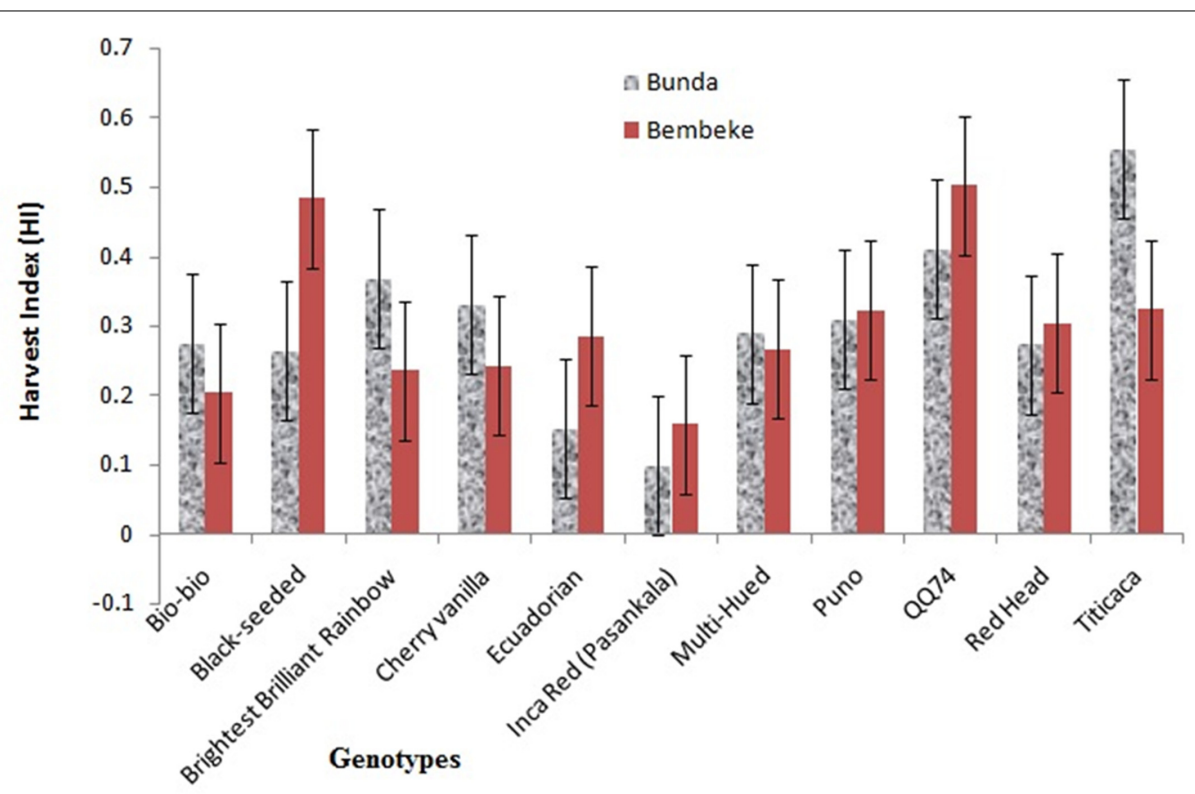

FIGURE 4 | Harvest indices (HI) of quinoa varieties grown at Bunda and Bembeke sites in Malawi from July to October 2012 ( $P=0.001$ for genotype, $P=0.998$ for environment, and $P=0.039$ for $G \times E)$. 
yield was strongly correlated to biomass ( $r=0.87 ; p<0.001)$, plant height $(r=0.74 ; p<0.001)$ and days to maturity $(r=0.76$; $p<0.001)$ under irrigation. The faster maturing varieties were typically among the highest yielding. Yield differences among quinoa varieties are commonly observed, often due to differences in heat or drought tolerance (Pulvento et al., 2010; Gonzalez et al., 2012). For example, a 2 years study in Italy reported that Regalona Baer performed better than KVLQ520Y under rainfed conditions, most likely due to higher tolerance to high temperatures associated with water stress (Pulvento et al., 2010).

When grown under rainfed conditions at Bunda, differences $(P \leq 0.001)$ were found for grain yield, plant biomass and seed size among the 11 varieties (Table 4 ). The highest yielding genotype was Black Seeded (2050 kg/ha) followed by MultiHued $(1603 \mathrm{~kg} / \mathrm{ha})$ and Bio-Bio $(1446 \mathrm{~kg} / \mathrm{ha})$. Similar results of these two varieties were obtained from the trials under irrigated conditions where Multi-Hued was the highest performer in Bembeke $(624 \mathrm{~kg} / \mathrm{ha})$ and fourth highest performer in Bunda (2916 kg/ha). This indicates potential for broad adaptation in the variety Multi-Hued, whereas others are perhaps more narrowly adapted to specific environments. For example, Bio-Bio and Black Seeded were the 2nd and 4th highest performers in Bembeke, but among the lowest performers in Bunda. Further testing in multiple years across multiple locations in Malawi is needed to better understand the adaptation potential in these varieties. In general, varieties grown at Bunda under rainfed conditions were lower yielding compared to the same varieties at the same location under irrigated conditions. This was due in part to the poor establishment of the crop in the rainy season, as some plants were heavily affected by heavy storm damage post-emergence. These results support other studies that show mitigation of plant stresses may help to increase yields. Geerts et al. (2008) found that well-planned deficit irrigation can stabilize quinoa yields between 1.2 and $2 \mathrm{Mg} /$ ha in the central Bolivian Altiplano. For maximum production, drought stress should be mitigated by irrigation during plant establishment, flowering and early grain fill (Geerts et al., 2008).

\section{Harvest Index}

Multi-Hued had the highest biomass yield (3612 kg/ha) followed by Black Seeded (3163 g/ha) and Bio-Bio (2942 g/ha). Interestingly, varieties with the highest grain yield also produced a lot of biomass compared to the low yielding genotypes. This could be an important consideration when developing agronomic strategies for sustainable intensification of farming systems which include quinoa as a rotational crop. There were also significant differences among varieties for seed weight. Cherry Vanilla (2.4 g) and QQ74 (2.6 g) had biggest seeds whilst Ecuadorian (1.9 g) had the lowest seed weight. Bertero et al. (1999) found that seed size was reduced under long day and hot temperatures 21 days after anthesis. Seed size was reduced by $73 \%$ in the long day hot temperature treatments $\left(16 \mathrm{~h}\right.$ at $\left.28^{\circ} \mathrm{C}\right)$ compared to the short day and cool-temperature treatments $\left(10.25 \mathrm{~h}\right.$ at $21^{\circ} \mathrm{C}$ ) (Bertero et al., 1999).

A significant interaction between genotype and environment was found for the harvest indices $(P \leq 0.05)$. Genotype was also significantly different. Titicaca had highest harvest index $(0.555)$ at Bunda, whereas the QQ74 had high harvest index (0.503) at Bembeke (Figure 4). The varieties had a harvest index range of 0.099-0.555 at Bunda and 0.203-0.503 at Bembeke. Harvest index is an excellent parameter to assess the dry matter partitioning and efficiency of plants for mobilization of photo assimilates. Most of the genotypes showed to have high efficiency in their ability to partition dry matter into photo assimilate as their harvest index ranged from 0.3 to 0.5 ; this resulted into high yields.

Spehar and Santos (2005) reported that positive association among dry matter production, plant height and grain yield is translated to maturity period of the quinoa plants; where later maturing genotypes grew taller than the ones that matured early, and were also shown to be superior in other yield components. However, the study results also showed exceptions for harvest index where there were low values for late and high values for early maturing genotypes, which suggest a possibility to develop quinoa for high grain and biomass production to suit different farming systems.

\section{CONCLUSION}

Results of the experiments have shown that quinoa can grow well under varying agro-ecological zones in Malawi, from warmer to cooler areas. However, severely reduced grain yield may occur if quinoa is grown in the highland areas of Malawi during the winter season and emergence is insufficient. The results also highlight the need to continue evaluating a diverse number of cultivars to select for genotypes adapted to specific agroecological areas across seasons in Malawi. Grain yield is the basic motive for the cultivation of cereals and pseudo-cereals. Significant variation among varieties for grain yield was found at each location, indicating the importance or regional variety trials and the establishment of a quinoa breeding program in Malawi that can effectively optimize seed yield in target environments across the region.

\section{AUTHOR CONTRIBUTIONS}

MM conceived and conducted the field trials. JN and VG assisted in the data collection. KM provided the quinoa seed for the experiments and assisted MM in the initial development of the project. MM and KM took primary responsibility for writing the manuscript.

\section{FUNDING}

Funding for this project was generously provided by the office of International Research and Development at Washington State University.

\section{ACKNOWLEDGMENTS}

The authors acknowledge funding and seed of the quinoa varieties (used in this study) from Washington State University 
for the irrigated experiments at Bunda Campus of Lilongwe University of Agriculture and Natural Resources (LUANAR) and at Bembeke Agricultural Research Substation of Department of

\section{REFERENCES}

Adams, S. R., Cockshull, K. E., and Cave, C. R. J. (2001). Effect of temperature on the growth and development of tomato fruits. Ann. Bot. 88, 869-877. doi: 10.1006/anbo.2001.1524

Adolf, V. I., Shabala, S., Andersen, M. N., Razzaghi, F., and Jacobsen, S.-E. (2012). Varietal differences of quinoa's tolerance to saline conditions. Plant Soil 357, 117-129. doi: 10.1007/s11104-012-1133-7

Alberta Agriculture Food and Rural Development [AAFRD] (2005). Quinoa-The Next Cinderella Crop for Alberta? A Report by Alberta Agriculture, Food and Rural Development (AAFRD). Available at: http://wwwl.agric.gov.ab.ca/ $\backslash$ protect $\backslash \mathrm{T} 1 \backslash$ textdollardepartment/deptdocs.nsf/all/afu9961

Aluwi, N., Gu, B.-J., Dhumal, G., Medina-Meza, I. G., Murphy, K. M., and Ganjyal, G. (2016). Impacts of scarification and degermination on the expansion characteristics of select quinoa varieties during extrusion processing. J. Food Sci. 81, E2939-E2949. doi: 10.1111/1750-3841.13512

Babatunde, R. O., Olungunju, F. I., Fakayode, S. B., and Sola-Ojo, F. E. (2011). Prevalence and determinants of malnutrition among under five children of farming households in Kwara State, Nigeria. J. Agric. Sci. 3, 173-181. doi: 10.5539/jas.v3n3p173

Bazile, D., Jacobsen, S.-E., and Vernaiu, A. (2016). The global expansion of quinoa: trends and limits. Front. Plant Sci. 7:622. doi: 10.3389/fpls.2016.00622

Bertero, H. D., de la Vega, A. J., Correa, G., Jacobsen, S.-E., and Mujica, A. (2004). Genotype and genotype-by-environment interaction effects for grain yield and grain size of quinoa (Chenopodium quinoa Willd.) as revealed by pattern analysis of international multi-environment trials. Field Crops Res. 89, 299-318. doi: 10.1016/j.fcr.2004.02.006

Bertero, H. D., King, R. W., and Hall, A. J. (1999). Photoperiod-sensitive development phases in quinoa (Chenopodium quinoa Willd.). Field Crops Res. 60, 231-243. doi: 10.1016/S0378-4290(98)00128-2

Bhargava, A., Shukla, S., Rajan, S., and Ohri, D. (2007). Genetic diversity for morphological and quality traits in quinoa (Chenopodium quinoa Willd.) germplasm. Genet. Res. Crop Evol. 54, 167-173. doi: 10.1007/s10722-0053011-0

Cusack, D. F. (1984). Quinoa: grain of the Incas. Ecologist 14, 21-23.

Food, and Agriculture Organization of the United Nations [FAO] (2012a). Economic Growth is Necessary but not Sufficient to Accelerate Reduction of Hunger and Malnutrition. Rome: FAO.

Food and Agriculture Organization of the United Nations [FAO] (2012b). Master Plan for the International Year of Quinoa-a Future Sown Thousands of Years Ago. Available at: http://www.fao.org/fileadmin/templates/aiq2013/res/ en/master_plan.pdf

Garcia, M., Raes, D., and Jacobsen, S.-E. (2003). Evapotranspiration analysis and irrigation requirements of quinoa (Chenopodium quinoa) in the Bolivian highlands. Agric. Water Manag. 60, 119-134. doi: 10.1016/S0378-3774(02) 00162-2

Geerts, S., Raes, D., Garcia, M., Vacher, J., Mamani, R., Mendoza, J., et al. (2008). Introducing deficit irrigation to stabilize yields of quinoa (Chenopodium quinoa Willd.). Eur. J. Agron. 28, 427-436. doi: 10.1016/j.eja.2007. 11.008

Gonzalez, J. A., Konishi, Y., Bruno, M., Valoy, M., and Prado, F. E. (2012). Interrelationships among seed yield, total protein and amino acid composition of ten quinoa (Chenopodium quinoa) cultivars from two different agroecological regions. J. Sci. Food Agric. 92, 1222-1229. doi: 10.1002/jsfa.4686

Hirich, A., Choukr-Allah, R., and Jacobsen, S.-E. (2014). Deficit irrigation and organic compost improve growth and yield of quinoa and pea. J. Agron. Crop Sci. 200, 390-398. doi: 10.1111/jac.12073

Jacobsen, S.-E. (2003). The worldwide potential for quinoa (Chenopodium quinoaWilld.). Food Rev. Int. 19, 167-177. doi: 10.1081/FRI-120018883

Jacobsen, S.-E., and Bach, A. P. (1998). The influence of temperature on seed germination rate in quinoa (Chenopodium quinoa Willd.). Seed Sci. Technol. 26, 515-523.
Agricultural Research and Services; and Department of Crop and Soil Sciences of LUANAR for supporting the rain-fed experiments.

Jacobsen, S.-E., Hill, J., and Stølen, O. (1996). Stability of quantitative traits in quinoa (Chenopodium quinoa). Theor. Appl. Genet. 93, 110-116. doi: 10.1007/ BF00225735

Jacobsen, S.-E., Monteros, C., Corcuera, L. J., Bravo, L. A., Christiansen, J. L., and Mujica, A. (2007). Frost resistance mechanisms in quinoa (Chenopodium quinoa Willd.). Eur. J. Agron. 26, 471-475. doi: 10.1016/j.eja.2007. 01.006

Jacobsen, S.-E., and Mujica, A. (2003). The worldwide potential for quinoa (Chenopodium quinoa Willd.). Food Rev. Int. 19, 167-177. doi: 10.1081/FRI120018883

Jacobsen, S.-E., Mujica, A., and Jensen, C. R. (2003). The resistance of quinoa (Chenopodium quinoa Willd.) to adverse abiotic factors. Food Rev. Int. 19, 99-109. doi: 10.1081/FRI-120018872

Jacobsen, S.-E., and Stølen, O. (1993). Quinoa morphology, phenology and prospects for its production as a new crop in Europe. Eur. J. Agron. 2, 19-29. doi: 10.1016/S1161-0301(14)80148-2

Jayne, T. S., Yamano, T., Weber, M. T., Tschirley, D., Benfica, R., and Chapoto, A. (2003). Smallholder income and land distribution in Africa: implications for poverty reduction strategies. Food Policy 28, 253-275. doi: 10.1016/S03069192(03)00046-0

Kathabwalika, D. M., Chilembwe, E. H. C., Mwale, V. M., Kambewa, D., and Njoloma, J. P. (2013). Plant growth and yield stability of orange fleshed sweetpotato (Ipomea batatas L.) genotypes in three agro-ecological zones of Malawi. Int. Res. J. Agric. Sci. Soil Sci. 3, 383-392.

Kowalski, R. J., Medina-Meza, I. G., Thapa, B. B., Murphy, K. M., and Ganjyal, G. M. (2016). Extrusion processing characteristics of quinoa (Chenopodium quinoa Willd.) var. Cherry Vanilla. J. Cereal Sci. 70, 91-98. doi: 10.1016/j.jcs. 2016.05.024

Long Nguyen, V. (2016). Effects of salinity stress on growth and yield of quinoa (Chenopodium quinoa Willd.) at flower initiation stages. Vietnam J. Agric. Sci. $14,321-327$.

Maliro, M. F. A., and Guwela, V. (2015). “Quinoa breeding in Africa: history, goals, and progress", in Quinoa: Improvement and Sustainable Production, eds K. M. Murphy and J. G. Matanguihan (Hoboken, NJ: Wiley-Blackwell).

Ministry of Natural Resources, Energy and Environment [MoNREE] (2013). Climate of Malawi. Department of Climate Change and Meteorological Services (DCCMS) of the Ministry of Natural Resources, Energy and Environment (MoNREE). Available at http://www.metmalawi.com/climate/climate.php

Murphy, K. M., Bazile, D., Kellogg, J., and Rahmanian, M. (2016). Development of a worldwide consortium on evolutionary participatory breeding in quinoa. Front. Plant Sci. 7:608. doi: 10.3389/fpls.2016.00608

National Statistical Office [NSO] (2010). Malawi Demographic and Health Survey 2010. Zomba: National Statistical Office, 129-150.

Oelke, E. A., Putnam, D. H., Teynor, T. M., and Oplinger, E. S. (1992). Quinoa. Alternative Field Crops Manual University of Wisconsin-Extension. Available at http://www.hort.purdue.edu/newcrop/afcm/quinoa.html [accessed March 27, 2014].

Oyoo, M. E., Githiri, S. M., and Ayiecho, P. O. (2010). Performance of some quinoa (Chenopodium quinoa Willd.) genotypes in Kenya. S. Afr. J. Plant Soil 27, 2.

Peterson, A., and Murphy, K. M. (2014). "Quinoa in the USA and Canada," in The State of the World's Quinoa, ed. D. Bazile (Rome: Food and Agriculture Organization).

Peterson, A., and Murphy, K. M. (2015a). Tolerance of lowland quinoa cultivars to sodium chloride and sodium sulfate salinity. Crop Sci. 55, 331-338. doi: 10.3389/fpls.2016.00790

Peterson, A., and Murphy, K. M. (2015b). "Quinoa cultivation for temperate north america: considerations and areas for investigation," in Quinoa: Improvement and Sustainable Production, eds K. M. Murphy and J. G. Matanguihan (Hoboken, NJ: Wiley-Blackwell).

Peterson, A. J., Jacobsen, S.-E., Bonifacio, A., and Murphy, K. M. (2015). A crossing method for quinoa (Chenopodium quinoa). Sustainability 7, 3230-3243. doi: $10.3390 /$ su7033230 
Pulvento, C., Riccardi, M., Lavini, A., D’Andria, R., Iafelice, G., and Marconi, E. (2010). Field trial evaluation of two Chenopodium quinoa genotypes grown under rain-fed conditions in a typical Mediterranean environment in south Italy. J. Agron. Crop Sci. 196, 407-411. doi: 10.1111/j.1439-037X.2010.00431.x

Rojas, W., Barriga, P., and Figueroa, H. (2000). Multivariate analysis of the genetic diversity of Bolivian quinoa germplasm. PGR Newsletter 122, 16-23.

Ruiz, K. B., Aloisi, I., Del Duca, S., Canelo, V., Torrigiani, P., Silva, H., et al. (2016). Salares versus coastal ecotypes of quinoa: salinity responses in Chilean landraces from contrasting habitats. Plant Phys. Biochem. 101, 1-13. doi: 10.1016/j.plaphy. 2016.01.010

Schlick, G., and Bubenheim, D. L. (1996). "Quinoa: candidate crop for NASA's controlled ecological life support systems," in Progress in New Crops, ed. J. Janick (Arlington, VA: ASHS Press), 632-640.

Snedecor, G. W., and Cochran, W. G. (1989). Statistical Methods, 8th Edn. Ames, IA: Iowa State University Press.

Spehar, C. R., and Santos, R. L. B. (2005). Agronomic performance of quinoa selected in the Brazilian Savannah. Pesq. Agropec. Bras. Brasilia 40, 609-612. doi: 10.1590/S0100-204X2005000600012

Sun, Y., Liu, F., Bendevis, M., Shabala, S., and Jacobsen, S.-E. (2014). Sensitivity of two quinoa (Chenopodium quinoa Willd.) varieties to progressive drought stress. J. Agron. Crop Sci. 200, 12-23. doi: 10.1111/jac.12042

United Nations [UN] (2012). United Nations Resolution on the Declaration of the IYQ 2013. A Resolution Adopted by General Assembly-A/RES/66/221 in March 2012. Available at http://www.un-ngls.org/IMG/pdf/IYQ.pdf
Walters, H., Carpenter-Boggs, L., Desta, K., Yan, L., Matanguihan, G. J., and Murphy, K. M. (2016). Effect of irrigation, intercrop and cultivar on agronomic and nutritional characteristics of quinoa. Agroecol. Sust. Food Syst. 40, 783-803. doi: 10.1080/21683565.2016.1177805

Wilson, H. D. (1990). Quinoa and relatives (Chenopodium sect. chenopodium subsect. cellulata). Econ. Bot. 44(Suppl. 3), 92-110. doi: 10.1007/BF028 60478

Wu, G., Murphy, K. M., and Morris, C. (2014). Evaluation of texture differences among varieties of cooked quinoa. J. Food Sci. 79, S2337-S2345. doi: 10.1111/ 1750-3841.12672

Wu, G., Peterson, A. J., Morris, C. F., and Murphy, K. M. (2016). Quinoa seed quality response to sodium chloride and sodium sulfate salinity. Front. Plant Sci. 7:790. doi: 10.3389/fpls.2016.00790

Conflict of Interest Statement: The authors declare that the research was conducted in the absence of any commercial or financial relationships that could be construed as a potential conflict of interest.

Copyright (c) 2017 Maliro, Guwela, Nyaika and Murphy. This is an open-access article distributed under the terms of the Creative Commons Attribution License (CC BY). The use, distribution or reproduction in other forums is permitted, provided the original author(s) or licensor are credited and that the original publication in this journal is cited, in accordance with accepted academic practice. No use, distribution or reproduction is permitted which does not comply with these terms. 